p-ISSN 0044-1600

e-ISSN 2392-3458
Zagadnienia Ekonomiki Rolnej

Problems of Agricultural Economics

$4(357) 2018,117-140$

\title{
CYCLICAL FLUCTUATIONS IN THE PRODUCTION OF POLISH AGRICULTURE
}

\author{
ANDRZEJ JECDRUCHNIEWICZ
}

\begin{abstract}
The main objective of the study is the quantitative characteristics of the business cycle in agriculture in Poland in 1991-2016. The first part of the article is devoted to the theory of cyclical fluctuations in the agriculture. The second part includes an empirical analysis. The investigation of the agricultural business cycle is based on the year-to-year dynamics of the gross value added and final output. On the basis of the added value it was possible to identify four full cycles: (1) 1996-2000; (2) 2001-2006; (3) 2007-2012; (4) 2013-2015. Using the final output, it was considered that also in this case, four cycles can be determined: (1) up to 2000; (2) 2001-2006; (3) 2007-2010; (4) 2011-2015. The cycles' duration was usually 3-6 years. However, the phases most frequently lasted from 2 to 4 years. On the basis of the analysis, it was also concluded that the amplitude of the entire cycle of gross value added as well as of its individual phases was always, in absolute terms, higher than the amplitude of the final production cycle and phases. The highest absolute amplitude was observed for the cycle of gross value added in 2013-2015.
\end{abstract}

Keywords: business cycle, agriculture, gross value added, final agricultural output.

JEL codes: E23, E32, Q11, Q19.

Dr hab. Andrzej Jędruchniewicz, Szkoła Główna Gospodarstwa Wielkiego, Wydział Nauk Ekonomicznych, Katedra Ekonomii i Polityki Gospodarczej; ul. Nowoursynowska 166, 02-787 Warszawa (andrzej_jedruchniewicz@sggw.pl). ORCID iD: 0000-0002-3133-6880. 


\section{Introduction}

The business cycle is one of the key and rather complex economic issues. Theoretical and empirical research have been conducted for a long time to explore this phenomenon in more detail (see Barczyk, Lubiński and Małecki, 2014; Kaletsky, 2010; Snowdon and Vane, 2005; Garrison, 2001; Romer, 2000). Despite extensive literature on the issue there are still some issues requiring more precise analyses, which has been proved by the last crisis underrating the role of the financial institutions (Schiff, 2015; Kwaśnicki, 2014; Roubini and Mim, 2011; Wojtyna (ed.), 2011; Sławiński, 2009). As the macroeconomic approach prevails in the works by economists, changes in economic categories that affect the entire economy are most often examined. Analyses devoted to economic fluctuations in particular sectors are relatively rare, as economists focus primarily on changes in industry.

In developed countries, also in Poland, the agricultural sector accounts for a small part of domestic output. However, due to connections with the entire economy through, e.g. supplies of raw materials to the food industry, the impact on food prices and the purchase of agricultural inputs, agriculture is an important part of the economy. Research into business cycles in this sector is important. They enable to deepen the knowledge of reasons, mechanisms and outcomes of cyclical changes in key categories for agriculture, i.e. a sector strongly dependent on the natural conditions and producing raw materials of low price elasticity of demand. Better recognition of the process may influence enhancement of the economic policy in agriculture and making less errors in forecasts.

The main objective of the study is to identify and quantify business cycle and its particular phases in the Polish agriculture. The analysis of cyclical fluctuations will be based on the agricultural production growth rate, with the use of gross value added and final agricultural output. A comparison of the morphology of business cycles will also be made based on changes in these two categories. The use of output changes to analyse changes in the overall economic situation is frequent, but it is rarely used in research relating to agriculture.

\section{Business cycle and its measurement}

Economic fluctuations have been of particular interest to economists for over one hundred years. They are one of the types of fluctuations in the economy, along with the trend and seasonal and irregular fluctuations. They are characterized by a fixed pattern and an unspecified rhythm, which means that they occur at irregular intervals (see Barczyk, Kąsek, Lubiński and Marczewski, 2006). There were different definitions of the cycle throughout years. The classic definition was formulated by Burns and Mitchell (1946, p. 3):

"Business cycles are a type of fluctuation found in the aggregate economic activity of nations that organize their work mainly in business enterprises: a cycle consists of expansions occurring at about the same time in many economic activities, followed by similarly general recessions, contractions, and revivals which merge into the expansion phase of the next cycle." 
A classic cycle consists of four phases, referred to differently by various economists (see Barczyk, 2000-2001). Another older definition is more general and mentions only two phases: "cyclical fluctuations are wave-like fluctuations of business activity characterized by recurring phases of expansion and contraction in periods longer than a year" (Estey, 1959, p. 6). What these two definitions have in common is the use of output volumes in absolute terms.

It may happen, however, that the economy does not experience an absolute decrease in the output volume year-on-year for a very long time, e.g. for ten or twenty years. This was the case, for example, in the countries of Western Europe after the Second World War. Then, it is impossible to analyse cyclical changes using the classical approach. Therefore, Mintz (1972, p. 41) proposed analysis of a growth cycle based on the rates of output growth: "growth cycles are fluctuations in aggregate economic activity. A growth cycle consists of a period of relatively high growth rates occurring at about the same time in many economic activities, followed by a period of similarly widespread low growth rates which merges into the high-growth phase of the next cycle". Nowadays, this approach, i.e. the use of relative changes in the output volume, prevails. So does analysis of two phases, i.e. a favourable economic situation and an unfavourable one. In some cases, however, especially when there is a drop in output, four phases should rather be identified in a cycle based on the output growth.

Determining a business cycle is always a difficult task, and obtained results are usually debatable. This is due to the multiplicity of interrelated factors affecting the activity of business entities. As mentioned before, they take a form of a trend as well as cyclical, seasonal and irregular changes. "Any selection of so conceived components of economic development is conventional and is carried out under numerous assumptions. Using different methods (...) the obtained results in the form of final cycle parameters usually vary" (Drozdowicz-Bieć, 2012, p. 22).

The determination of a cycle and its phases can be done using numerous methods, such as business barometers, economic situation testing, econometric methods, expert methods (Lubiński, 2004). In practice, sectoral research most often use the first two. Business barometer is an index composed of adequately selected economic indices, which allow for observation of the current economic situation and forecast of its changes (see Matkowski (ed.), 2004). A definite advantage of the measure is its plain and clear construction and easy use. But it has disadvantages as well. The key objections to the business barometer include: lack of theoretical justification for the selection of variables to the complex index and issues concerning statistical data.

The economic situation testing is surveys opinions of entrepreneurs and consumers to assess the current and forecast economic situation. The main difference between it and the business barometer is that the economic situation testing uses only subjective answers of the entities. But similarly to the barometer it is a qualitative measure, which provides an important supplement to quantitative data (Kowalczyk, 2011). Questions for the participants most often have three simple answers: growth, no change, drop. After obtaining them, the percentage share of each of them is calculated and a balance is indicated that is a difference between positive 
and negative scores. The balance takes on the values from -100 to +100 . The biggest advantages of the test include: up-to-date information, regularity of opinions, and ease of analysis. Whereas the greatest disadvantages cover: lack of theoretical grounds, sensitivity of qualitative data to changes in the situation of the business entities and subjectivity of answers (Róg and Strzała, 2011).

These methods are quite complicated or are based on subjective assessments of the economic situation. Using aggregated categories is a more commonly used and simpler method. This requires selection of one or several categories which should adequately describe changes in production in the economy or an industry, and should be based on data collected and disseminated by a credible institution. In the economy, gross domestic product is most commonly used as such a category. Presently, in order to separate the cyclical component mainly the methods basing on trend deviation are used. The trend is set and eliminated by mechanical methods, e.g. Hodrick-Prescott filter, Baxter-King filter or Christiano-Fitzgerald spectral filter, first differences or modelling of time series components with special consideration given to the trend.

\section{Theory of cyclical fluctuations in agriculture}

The theory of business cycle regarding its course and causes as well as characteristics of its particular phases is very diverse. It consists of theories of schools and theories of individualist economists. It can be divided into: (1) monetary theories (e.g. Friedman's theory, Lucas' theory, the Austrian School theory); (2) theories of inadequate demand (e.g. Keynes' theory, Kalecki's theory, theories of the new Keynesian School); (3) psychological theories (e.g. Minsky's theory, behavioural finance theory); (4) technological theories (Schumpeter's theory, real business cycle theory); (5) theories regarding the distribution of national income (mainly post-Keynesian and neo-Marxist theories) (see Kaletsky, 2010).

In modern economics, cyclical fluctuations in the economy are explained mainly through monetary theories, belonging to endogenous theories. Monetarism, a new classical school, and the Austrian School indicate that cyclical fluctuations are mainly due to the expansive policy of the central bank (Friedman and Schwartz, 1963; Lucas, 1987; Garrison, 2001). The new Keynesian School believes that it is aggregate demand that is responsible for cyclical fluctuations (Mankiw and Romer, 1991). New Keynesians admit that cyclical fluctuations may also occur on the supply-side of economics (Wojtyna, 2000). While the real business cycle theory explains fluctuations with exogenous and supply reasons (Plosser, 1989). This approach is interesting, but limited in analysis of cyclical fluctuations that occur relatively regularly (see Romer, 2000).

Most theories fail to fully convincingly explain the causes of cyclical fluctuations and describe their course. Some of the theories focus only on detailed, rather than fundamental, causes, while the others present only the general course of the cycle, thus they poorly explain the actual changes. Numerous theories emphasize also insignificant correlation between changes in the financial sector and the real sector (Wojtyna, 2013). 
Business cycles in the economy were initially explained by economists through fluctuations in agricultural output (Cameron and Neal, 2004). Poor harvest in agriculture increased the costs of raw materials and subsistence, which leads to a deteriorated economic situation in industry and trade. Jevons' sunspot theory is the best known early theory regarding cyclical fluctuations in agricultural output. Nowadays, it seems funny. However, Jevons, as an economist with free market views, tried to find exogenous reasons causing relatively regular crises in agriculture. Analysing data regarding fluctuations in agriculture, this economist noticed their significant convergence with changes in solar activity. He concluded that explosions on the Sun cause changes in natural conditions, which are the direct cause of changes in agricultural production. A decrease in plant production results in worse animal production conditions, leading to a crisis in the whole agriculture. Production decreases, while prices go up. Changes in agricultural raw material markets adversely affect other sectors of the economy, leading to a crisis throughout the economy (Jevons, 1878). This theory was not widely recognized. It was criticized mainly for taking into account an exogenous factor, relying solely on correlation instead of convincing economic grounds (Morgan, 1990).

The development of the thought regarding fluctuations in agricultural output failed due to the clash of two opposing concepts. The first one was consistent with the view that changes are caused by exogenous causes, professed by classical and neoclassical economists. But Jevons' concept regarding the solar activity was rejected. The focus was on factors that had solid substantive grounds in the analysis of causal relationships. The role of mechanization in agriculture, new varieties and methods of production as well as the growth of arable land were emphasized. The other concept focused on endogenous factors. Economists believed that there is an internal mechanism in agriculture that causes relatively regular fluctuations in agricultural activity. The focus was on the features of land as an input, that distinguish it from other inputs, the relationships between output and investment, and the cost-effectiveness of agricultural production (see Hansen, 1932).

In the early period of research into the cyclical nature of the economy, some economists, e.g. supporters of Jevons' theory, believed that changes in agriculture determine changes in aggregate economic activity. The other concept was opposite. Nowadays, it is undoubtedly the latter concept that properly describes the relationships between a cycle in the aggregate economic activity and a cycle in agriculture in the developed countries. It is mainly due to the very small share of agriculture in GDP in these countries and the considerable openness of their economies to world markets. The cyclical component of changes in agricultural output is, therefore, dependent on the economic situation in the entire national economy (see Dudek, 2014; Grzelak, 2013). Therefore, instead of trying to develop a separate theory describing cyclical fluctuations in agriculture, economists should rather rely on a theory that explains well changes in the economy. It should consider time delays in production and adequately formulated expectations.

Cyclical changes in the economy are realistically described by the theory of the Austrian School (Skousen, 2007). Although it is rejected by mainstream econo- 
mists, it has been growing in significance after the 2008 crisis. This theory is based on the theory of capital and production structure. Capital is the market value of capital goods. Whereas capital goods are heterogeneous goods used at every stage of production of consumer goods. These goods make up the production structure, i.e. production stages arranged in accordance with the technical process of the final good manufacturing. Such a production process must take time and must always be analysed from the time perspective. These stages, hence also goods, are distant, to a various extent, from the final good. Their quantity used determines the length of the production structure. The theory of the Austrian School states that to produce more consumer goods, it is necessary to adopt more capital-intensive and complicated methods of production, and thus to extend the production time.

Cyclical fluctuations in the economy are mainly due to the expansive policy of the central bank. Extra money encourages entrepreneurs to increase their investments that, according to their subjective expectations, will be more profitable. This means lengthening the production structure. Changes in production volume and prices at each stage are not the same (Skousen, 2007). Their increase is the greatest at the initial stages and small at the final ones. Agriculture most often produces raw materials. Thus, it is at the initial stages of the production structure. A better economic situation most often leads to a dynamic increase in production and prices in agriculture. This is in line with observations of agricultural economists:

"The presented dependencies confirm the principle of asymmetry of imbalance applied in economics, which provides that this asymmetry is the greatest at the beginning of the technological process (...) In the case of agriculture, any reduction in demand (in conditions of economic crisis) for final goods (i.e. food purchased by consumers) triggers an impulse for a decline in orders for finished goods, then semi-finished products, and finally agricultural raw materials, as a result of which the latter are exposed to the largest drop in demand and prices. In the opposite situation, an increase in orders applies to the largest extent to agriculture and makes prices rise" (Stępień 2011, p. 35).

The difference is that agricultural economists see the onset of changes only on the side of demand for final goods. For economists representing the Austrian School this is also important. They point out, however, that an increase in optimistic estimates of producers operating in industries at the early stages of the production process is of key importance. Therefore, both sides of the market are important - the demand and the supply side.

In the extension phase, growing investment and production lead to the extension and expansion of the production structure in the economy and agriculture (Jędruchniewicz, 2012). The extended time of production of final goods in isolation from demand for these goods is the main cause of a crisis. Increasing inflation and interest rates force companies to limit the financing of capital-intensive production processes. The fall in demand for investment goods triggers the contraction phase of the cycle. The production structure in the economy shortens and narrows. This process is the most pronounced at the initial stages. Therefore, declines in production and prices of agricultural products are more dynamic than in the case of final 
goods. Economists representing the Austrian School believe that a crisis is the time of eliminating investment mistakes. "The period of depression is, therefore, necessary for the economy to recover" (Rothbard, 2008, p. 410).

Besides cyclical fluctuations, there are also fluctuations on respective markets in agriculture. Special cycles have their specificity. These are most often explained by the cobweb mechanism. Although this theory is already eighty years old, it continues to be theoretically and empirically analysed by economists. This model is most often used to explain fluctuations in output and prices on the pig market (see Stępien, 2015; Stańko, 2012). The classic version of this theory is believed to be developed by Ezekiel (1938). The cobweb mechanism is an attempt to explain mutual cyclical adjustments of demand, supply and prices, which take place at certain time intervals. It is based on three assumptions: (1) there must be a time lag between the time of the decision to launch production and its implementation; (2) production plans of business entities are based on current prices or prices from recent periods; (3) current prices are mainly a function of current supply, which in turn depends on current output (Tomek and Robinson, 2003). This mechanism is based on delayed decisions of producers. The logic of events is as follows: changes begin as a consequence of some unfavourable event. It is usually assumed that unfavourable natural conditions result in a decrease in agricultural output, and thus also in current supply, leading to an increase in current prices of products. High prices encourage farmers to increase future output, which is always delayed due to the biological nature of agricultural production. In the next period, new higher supply leads to a reduction in prices, which are set at such a level as to offset demand with the new volume of sales (the model assumes that all output is sold). New lower prices induce farmers to lower future output, which leads to an increase in prices. These dependencies result in continuous adjustments of output and prices on agricultural markets.

The cobweb model was and is still criticized for, e.g.: (1) inability to explain longer cycles in agriculture; (2) analysis based on mechanical adjustments of output to current prices; (3) disregarding other factors, such as state interventions, atmospheric changes; (4) disregarding the costs of output adjustments, especially when the households have invested heavily in fixed assets; (5) failure to take into account price expectations in producers' decisions (Stilman, 1984; Chavas and Holt, 1995; Zawadzka, 2006). Therefore, the static model has been modified to make it more realistic. The mechanism of supply changes has been extended to include other factors, such as biological ones, and attempts have been made to take into account adjustment costs and realistically formulate price expectations.

Any model aimed at precise description, not to mention prediction, of complicated and changeable economic reality, including the cobweb mechanism (even when modified), is bound to fail (see Mayer, 1996; White, 1984). Nevertheless, this mechanism deserves attention because it takes into account two issues that are important for a realistic analysis of cyclical fluctuations on agricultural markets. First of all, in every production, i.e. also in agriculture, there are time lags between its impulse and implementation. These processes may be analysed only from the perspective of time. Second of all, the model accentuates producers' response to price 
changes. Therefore, it is important what prices are taken into account. Obviously, a response to current prices only, as provided for in the cobweb model, is unacceptable. The actions of each human are targeted at the future (Huerta de Soto, 2010). Analysis should, therefore, be guided by expected prices. There are controversies as to the type of expectations. Mainstream economists assume rational expectations. However, their occurrence in reality is highly doubtful (O'Driscoll and Rizzo, 1996). Everyone predicts the future in a subjective way, has limitations and access only to part of information that is dispersed. Therefore, adaptive and quasi-rational expectations seem more realistic, as confirmed by the findings of the research carried out by Chavas (1999).

\section{Research on the cycle in the Polish agriculture}

In Poland, this phenomenon has been analysed in a relatively small number of papers. One of the first to research this issue in market economy was Woś (1998). Using the synthetic business index he presented changes in the economic situation in agriculture. The research was relied on much delayed statistical data. Thus, they were of little use to agricultural policy, which was considered its major fault.

At another stage of the analysis of cyclicality economists from the Institute of Agricultural and Food Economics - National Research Institute draw up a synthetic business index in agriculture (SBIA) (Seremak-Bulge, 2000-2016). Results are published monthly, which makes them very up-to-date. This should be assessed positively since situation in the sector may be assessed almost on an on-going basis. The synthetic business index in agriculture is calculated as an arithmetic mean of the price scissors index and potential demand index. These in turn contain many detailed categories and indicators. On the one hand, this is an advantage of the measure because it tries to reflect the conditions in agriculture as accurately as possible. But on the other hand, it largely bases on subjective selection of variables and weights.

Researchers from the Collegium of Economic Analysis of Warsaw School of Economics to assess the changes in the economic situation in agriculture used the economic situation testing (Szajner and Walczyk, 2016-2018; Gorzelak and Zimny, 2010-2014). It bases on the responses of around 2 thousand farms, which can choose between positive, negative and neutral answers. Results from the analysis of the responses are presented once each quarter. The change of the situation in agriculture is presented with the use of the overall business index (OBI), which is calculated as the arithmetic average of the cash revenue change index and the trust index. The research covers also detailed issues important for farms, e.g. savings, debt, investments. Economic situation testing is used by the Central Statistical Office to analyse the changes in the situation of the sector (GUS, 2012-2018). An advantage of the method is timeliness of the information and clear method of economic situation assessment. But the greatest problem lies in subjectivity of respondents.

Comparisons of the results of the above business measurement methods are included in the works by Grzelak (2014) and Grzelak and Seremak-Bulge (2014). The authors conclude that the synthetic business index in agriculture, the overall busi- 
ness index and GUS index well illustrate the changes in the business cycle in agriculture. This in particular refers to the development trends. The synthetic business index in agriculture may be considered a barometer for the overall business index.

Quite a lot of works is devoted to the relations between changes in agricultural production and the cycle in the entire economy. Stępien (2011) reckons that along with global economy development and globalisation processes the interrelations between the business cycle and the situation in the agricultural sector is increasingly weaker. The paper is more deductive, and less empirical, though. Grzelak (2013) arrives at different conclusions. Based on the comparisons of indicators calculated by the Collegium of Economic Analysis of Warsaw School of Economics, the author states that in agriculture and economy there was greater harmonization of the course of business cycle fluctuations, lower asymmetry of cycles in agriculture and amplitude. Accession to the EU increased stabilisation of the business cycle in agriculture. Results of the analysis by Dudek (2014) indicates that general trends concerning the entire economy of changes are approximate to those present in the agricultural sector. However, the economic and financial situation of farms was characterised by much greater fluctuations than the situation of market entities in total. This observation has been confirmed by Maśniak (2015). Using the theory of the business cycle by the Austrian School, he assessed that global and final output of agriculture has lower average growth rate than GDP and food industry. But both types of output were characterised by much greater variability than output in the entire economy and that of food products. Research based on this School's theory are prospective and may provide many interesting conclusions.

Some part of works is devoted to special cycles in the Polish agriculture, thus concerns respective branches. The greatest number of research focuses on the pig cycle (Stępień, 2015; Szymańska, 2012; Hamulczuk, 2006). Results concerning cyclicality of output on respective agricultural markets will not be discussed, because it is not the subject of this study.

\section{Research methodology and data}

In aggregate economic activity, analysis of cyclical changes is most often based on quarterly data. GDP is announced with such frequency. Research into production fluctuations in agriculture is much more difficult due to the fact that only annual values of agricultural production are published. Therefore, the analysis of a cycle in Polish agriculture will be based in this paper on the annual growth rate of gross value added and that of final production in real terms. Gross value added (GVA) was adopted in the analysis as the main GDP calculation method is based on it. Values of GVA in agriculture cover the contribution of respective industries and types of plant and animal production. They show the difference between global output and intermediate consumption. GVA consists mainly of: labour costs, depreciation, financial costs, fees and taxes (excluding indirect taxes) and gross financial profit/ loss. Final output (FO) of agriculture is another category used to analyse a cycle. FO includes plant and animal production over a year. 
"The final agricultural output is the sum of the values of: commercial production, natural consumption of agricultural products from private production, the increase in stocks of plant and animal products and the increase in the value of the livestock population (basic and rotational herds). Final output, as opposed to global output, does not include those products from private production that have been used for production purposes, e.g. fodder, seed, manure" (GUS, 2017a, p. 52).

This category is much broader than gross value added, because it captures only a small part of elements constituting intermediate consumption. This is in line with the view presented by economists of the Austrian School, claiming that the assessment of changes in the economy should not disregard the production of intermediate goods (Skousen, 2007).

The study will focus on an expansion cycle. It is based on the analysis of changes in the growth rate of selected categories. In such cycle, only two phases are usually identified: expansion and contraction. However, in the study, each of these longer phases will be divided into two shorter ones. Thus, four phases will be identified in each full cycle. This approach is a combination of the elements of the modern cycle with elements of the classic cycle. This is in line with the business clock concept (Ruth, Schouten and Wekker, 2006). In this concept the growth rate of the analysed category can be in four phases: (1) above the trend and increasing; (2) above the trend and decreasing; (3) below the trend and decreasing; (4) below the trend and increasing. Therefore, in the study of a business cycle in agriculture, based on selected categories, two longer stages of the cycle will be identified: expansion and contraction. The expansion will be divided into two shorter phases: increasing dynamics below the trend and increasing dynamics above the trend. The contraction will be divided into two shorter phases as well, namely decreasing dynamics above the trend and decreasing dynamics below the trend.

In the analysis of cyclical fluctuations, determination of the turning points is of key importance. Although today more and more often they are referred to rather as turning zones than turning points. The peak of a business cycle falls when the dynamics of the selected category is at the highest point of the expansion and above the trend. The peak of the cycle is considered as the expansion phase. Then the cycle turns into the contraction phase. The trough of the cycle is defined in the same way. It is at the lowest point below the trend. The trough of the cycle is considered as the contraction phase. Then an expansion phase begins. In the study, a full business cycle of agricultural production was determined from its trough through the peak to the next trough (T-P-T). This enabled determination of the length of the cycles as well as their longer phases and amplitudes. Changes that lasted at least three years were considered a full cycle.

The research covers the period from 1991 to 2016, i.e. all years from the beginning of the transformation to the year for which statistics on the examined categories are available. At that time, the Polish economy experienced several periods of dynamic economic growth, as well as years of recession.

The data used in the study come from publications and websites of the Central Statistical Office and scientific studies. 


\section{The level and dynamics of agricultural output in Poland}

The significance of agricultural output in generating the domestic product can be determined by means of synthetic measures, i.e. its share in global output and the total gross value added (Mrówczyńska-Kamińska, 2008). The presented results relating to these measures indicate that the significance of agriculture in the Polish economy has been decreasing since the 1990s and is currently low (Fig. 1). In 2016, this sector generated $2.8 \%$ of the global output and $2 \%$ of the gross value added of the national economy. It is more than twice less than in 1995. This tendency and the share of agricultural production result from changes in the structure of the Polish economy, which is becoming similar to the structure of the economies of the most developed countries. Along with economic development, the growth rate of output in other sectors is getting faster than in agriculture. This process is confirmed by the place of agriculture in the economies of many Western European countries (see Czyżewski and Kułyk, 2017).

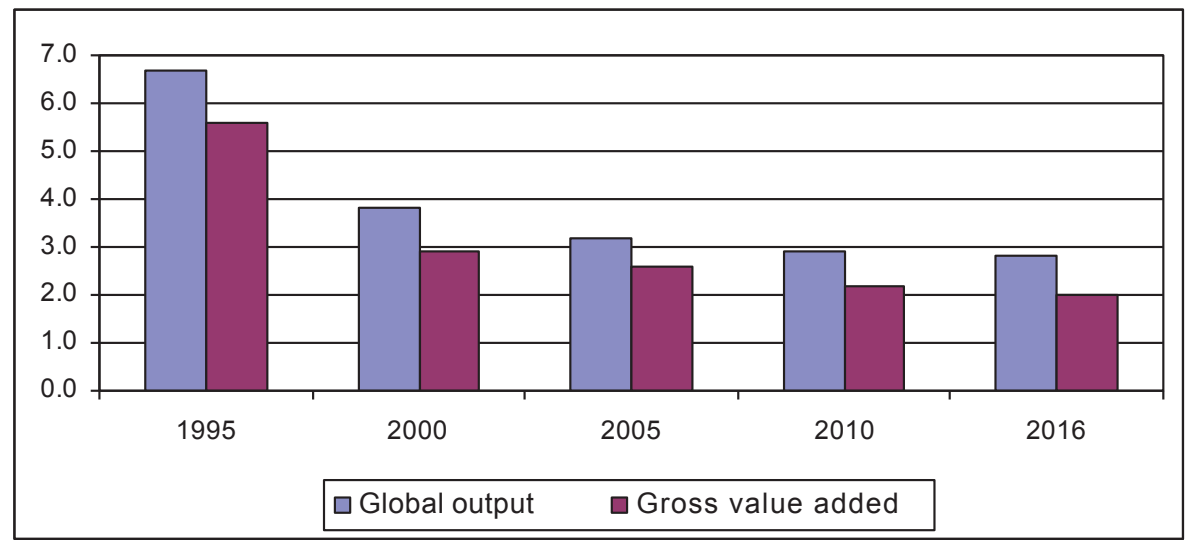

Fig. 1. Share of agriculture in global output and gross value added in Poland (\%). Source: the author's study based on GUS (1997-2017a) and GUS (1997-2017b).

Global output, gross value added and final output in agriculture were the highest in 2016 (Table 1). In 1995-2016, the values in these categories most often increased both when they were calculated at current prices and at constant prices. In these years, global output at current prices increased by $138.6 \%$, gross value added - by $145.2 \%$, and final output - by $207.2 \%$. Calculating at constant prices, global output increased only by $23.5 \%$, gross value added - by $26.3 \%$ (at that time, total GVA increased by $123.4 \%$ ), and final output increased by $46.9 \%$ (GUS, 1997-2017a; GUS, 2017b). The data show a slow increase in the volume of agricultural output in Poland and its limited share in generating national wealth in Poland by this sector

The analysis of the final output data shows that in all the above-mentioned years, animal production had a higher value, and thus also a larger share in total output, than plant production. From 1995 to 2016, the value of animal output at constant prices increased by $46.4 \%$, while that of plant production - by $40.4 \%$ (GUS, 2017b). 
Table 1

Value of agricultural output in Poland at current prices (PLN billion)

\begin{tabular}{lccccc}
\hline \multicolumn{1}{c}{ Category } & 1995 & 2000 & 2005 & 2010 & 2016 \\
\hline Global output & 43.3 & 56.0 & 63.3 & 84.4 & 103.3 \\
Gross value added & 15.7 & 16.7 & 22.3 & 31.2 & 38.5 \\
\hdashline $\begin{array}{l}\text { Total final output } \\
\text { of which: }\end{array}$ & 27.8 & 38.7 & 50.2 & 66.5 & 85.4 \\
plant & 11.2 & 14.1 & 19.1 & 28.9 & 36.3 \\
animal & 16.5 & 24.5 & 31.1 & 37.6 & 49.1 \\
\hdashline $\begin{array}{l}\text { Share of plant output } \\
\text { in total final output (\%) }\end{array}$ & 40.3 & 36.4 & 38.0 & 43.5 & 42.5 \\
$\begin{array}{l}\text { Share of animal output } \\
\text { in total final output (\%) }\end{array}$ & 59.4 & 63.3 & 62.0 & 56.5 & 57.5 \\
\hline
\end{tabular}

Source: GUS (1997-2017a) and the author's own calculations.

Figures 2 and 3 show the original time series regarding the annual dynamics of gross value added and final output of agriculture in real terms, moving averages calculated for two years and trend lines. The analysis of the original data clearly shows that until the mid-1990s, the volatility of these categories was much greater than in the later periods. The highest growth rate of gross value added was in 1991 . Then the annual growth amounted to $40.4 \%$ and radically deviated from the values over the entire period. Such a high volatility of these variables at the beginning of the analysed period was primarily due to: (1) the macroeconomic situation in the Polish economy which was undergoing transformation; (2) significant changes in the economic conditions in agriculture itself; (3) ownership and organizational changes on state farms.

Trend analysis indicated that it was shaped differently for both these categories. The trend of changes in the gross value added was decreasing. Since 2014 it has been reaching negative values. While the trend of changes in the final output has continued to grow. It has always reached positive values. These trends show increasing differences between output and efficiency of production. 


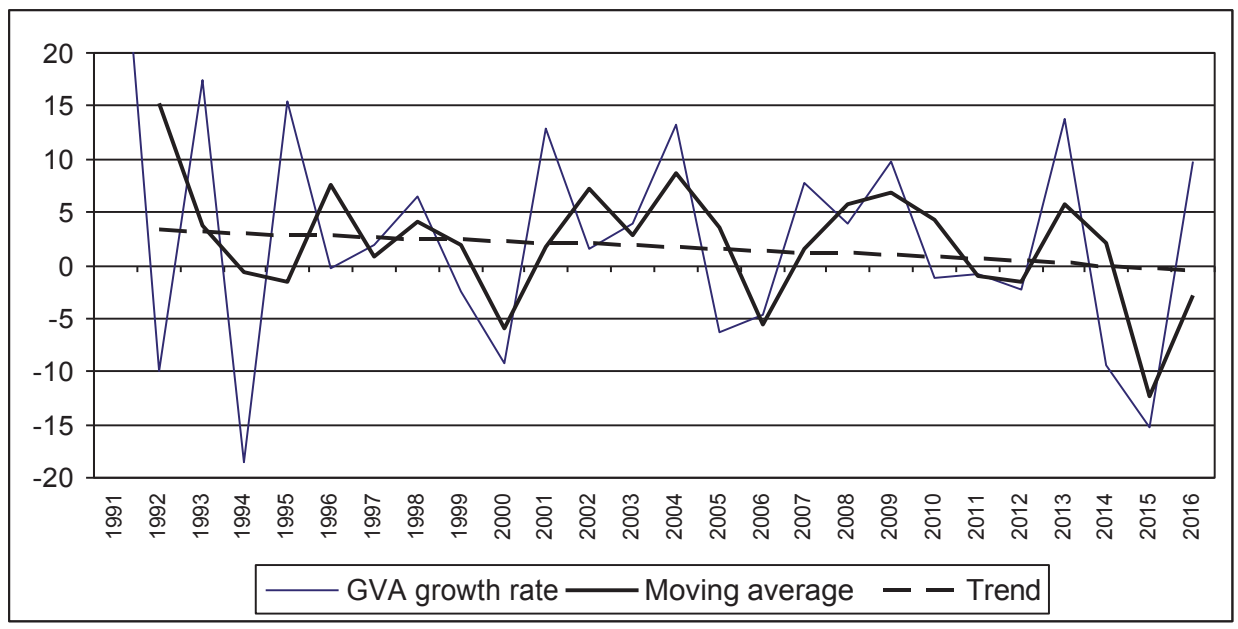

Fig. 2. Growth rate of gross value added of agriculture, moving average and trend (\%).

Source: the author's study based on GUS (1993-2017a).

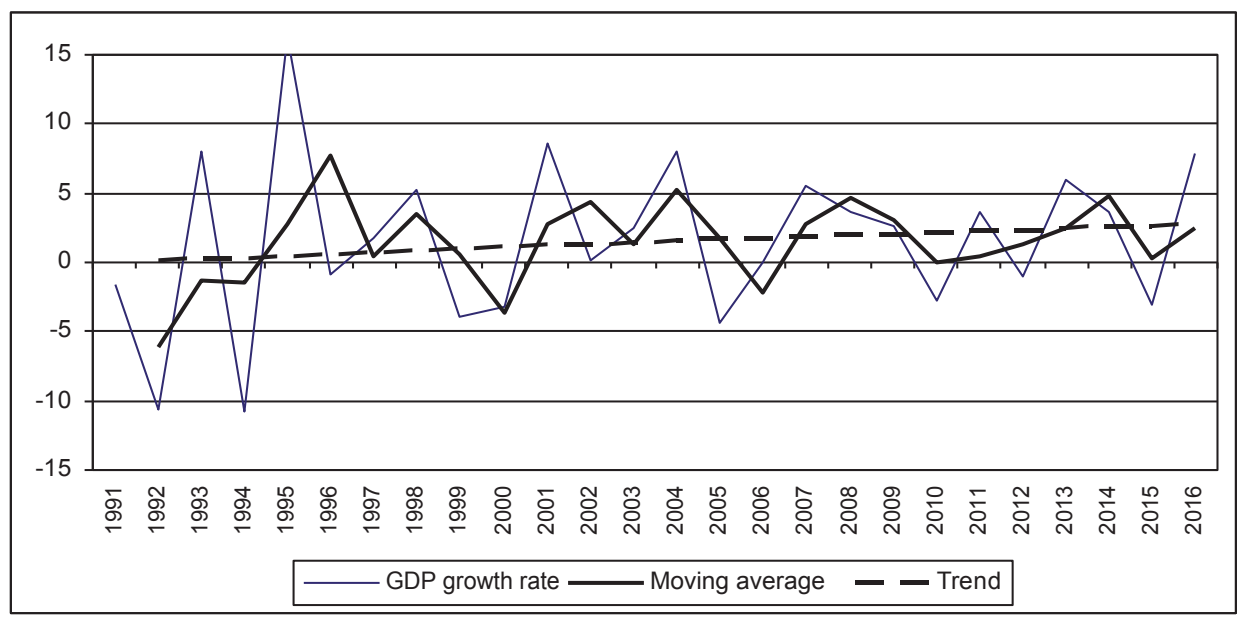

Fig. 3. Growth rate of final output of agriculture, moving average and trend (\%).

Source: the author's study based on GUS (1993-2017a).

To determine a cyclical component of changes in agricultural output, irregular changes had to be first eliminated, which was done using a moving average. It was used due to the relatively small number of observations, so as not to lose some of them at the beginning of the series (this is the case, for example, with Alexander's formula). This function smoothed the original data, which made it easier to extract cycles (Table 2). However, it needs to be noted that in several case it caused a movement in time of the turning points. But the movements were similar for both researched categories. Removal of accidental changes decreased the standard deviation of smoothed GVA data by $43.3 \%$ and GDP by $50.8 \%$. 
Table 2

Selected characteristics of the annual dynamics of gross value added and final output in agriculture in Poland (\%)

\begin{tabular}{lcccccc}
\hline \multirow{2}{*}{ Measure } & \multicolumn{3}{c}{ GVA } & \multicolumn{3}{c}{ GDP } \\
\cline { 2 - 7 } & $\begin{array}{c}\text { GUS } \\
\text { data }\end{array}$ & $\begin{array}{c}\text { Smoothed } \\
\text { data }\end{array}$ & $\begin{array}{c}\text { Smoothed/ } \\
\text { GUS }\end{array}$ & $\begin{array}{c}\text { GUS } \\
\text { data }\end{array}$ & $\begin{array}{c}\text { Smoothed } \\
\text { data }\end{array}$ & $\begin{array}{c}\text { Smoothed/ } \\
\text { GUS }\end{array}$ \\
\hline Mean & 1.5 & 2.1 & 1.40 & 1.7 & 1.5 & 0.88 \\
Median & 1.6 & 2.2 & 1.38 & 2.5 & 1.8 & 0.72 \\
Minimal value & -18.6 & -12.4 & 0.67 & -10.8 & -6.2 & 0.57 \\
Maximum value & 17.5 & 8.6 & 0.49 & 16.3 & 7.7 & 0.47 \\
Standard deviation & 9.7 & 5.5 & 0.57 & 6.1 & 3.0 & 0.49 \\
(percentage points) & 6.5 & 2.6 & 0.40 & 3.6 & 2.0 & 0.56 \\
Coefficient of variation & 6.5 &
\end{tabular}

Source: the author's own calculations based on GUS (1993-2017a).

The analysis of data presented in Figures 2 and 3, and from Table 2 as regards the dynamics of gross value added and final output shows that GVA was more variable in the analysed years than FO. It was characterized by a lower minimum value, a higher maximum value, a higher standard deviation and a higher coefficient of variation. Higher dynamics of changes in GVA than FO results from differences in the information content of these categories. GVA accounts for the surplus over total intermediate consumption. The value of intermediate goods largely depends on market conditions, which are highly volatile. Such variability is - apart from quantity changes - affected by major fluctuations in prices of resources used on farms. Final output of agricultural does not take into account only intermediate consumption from the farm's own output. This category is less dependent on the market conditions. Thus it is more stable.

\section{Morphology of business cycles in agriculture}

Identification of business cycles and their phases is a difficult task and its results are always disputable. The difficulty is even greater when fluctuations in agricultural production are analysed. This is due to the significantly greater volatility of output in this sector compared to the volatility of GDP. Agricultural output is much more susceptible to natural factors than any other type of manufactured goods, mainly industrial ones. Another difficulty results from the fact that only annual data on agricultural output are available, which is understandable in this type of production. This is particularly true for plant output. In most cases quarterly data are used, for example to analyse the cyclicality of industrial output.

The trend from the time series of gross value added and final output, generated following elimination of the irregular factor from the original data, was removed using the Hodrick-Prescott filter $(\lambda=10000)$. This enabled to more precisely separate the cyclical factor of changes in these categories. Points being the trough or peak of the cycle were also determined. The use of statistical methods for separat- 
ed cycles and adoption of specific assumptions regarding dating of turning points means that the obtained results are always sensitive to how the analysis is being conducted. This is also the case for this method. In 1992-2016, starting from the first expansion phase, four full business cycles were identified in agriculture based on GVA which lasted in the following periods (1) 1996-2000; (2) 2001-2006; (3) 2007-2012; (4) 2013-2015 (Fig. 4). Up to 1995, where the trough was indicated, there was the contraction phase.

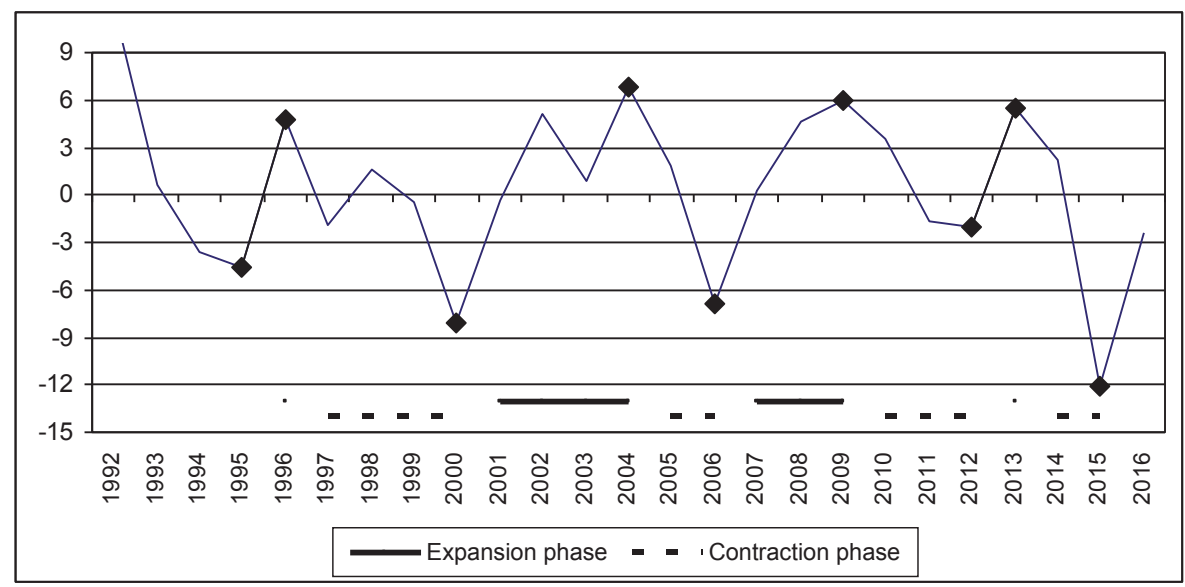

Fig. 4. Cyclical component of gross value added in agriculture (\%).

Source: the author's study based on GUS (1993-2017a).

The characteristics of the cycles and particular phases based on GVA are presented in Table 3. The duration of business cycles in agriculture was from 3 to 6 years. The shortest cycle was recorded in 2013-2015. Fluctuations from 2001-2006 were characterized by the longest expansion phase which lasted for four years. It was a period of prosperity in aggregate economic activity, just before Poland's accession to the European Union. The cycle amplitude was positive in the two middle cycles. The highest value of changes in GVA was recorded in 2007-2012 (4.9 pp). The highest negative cycle amplitude was in the last cycle. This means that the contraction in this cycle was much more dynamic than the expansion preceding it.

The duration of particular phases of the cycles in agriculture were usually harmoniously split into periods above and below the trend. Only the expansion from 2001-2004 consisted from one year below the trend and three years above the trend. It was also the phase with the highest dynamics of GVA growth. Its amplitude was $15 \mathrm{pp}$. At that time, the peak was also most deviated from the trend. As regards contractions, the 2014-2015 phase was characterized by the highest amplitude. It was also the time when the trough deviated most from the trend. As for the longest contraction, it was the one recorded in 1997-2000 (4 years). 
Table 3

Characteristics of cyclical fluctuations of gross value added in agriculture

\begin{tabular}{|c|c|c|c|c|c|c|}
\hline Cycle phase & $\begin{array}{c}\text { Period } \\
\text { of the cycle } \\
\text { phase }\end{array}$ & $\begin{array}{l}\text { Duration } \\
\text { of the phases } \\
\text { in years }\end{array}$ & $\begin{array}{c}\text { Period } \\
\text { and duration } \\
\text { of the cycle }\end{array}$ & $\begin{array}{l}\text { Peak/trough } \\
\text { deviation } \\
\text { from the trend } \\
\text { (pp) }\end{array}$ & $\begin{array}{l}\text { Amplitude } \\
\text { of the cycle } \\
\text { phases (pp) }\end{array}$ & $\begin{array}{l}\text { Amplitude } \\
\text { of the cycle } \\
\text { (pp) }\end{array}$ \\
\hline \multirow{6}{*}{$\begin{array}{l}\text { Expansion: } \\
\text { below the trend } \\
\text { above the trend } \\
\text { Contraction: } \\
\text { above the trend } \\
\text { below the trend }\end{array}$} & 1996 & 1 & \multirow{6}{*}{$\begin{array}{c}1996-2000 \\
5 \text { years }\end{array}$} & 4.7 & 9.3 & \multirow{6}{*}{-3.5} \\
\hline & - & - & & & & \\
\hline & 1996 & 1 & & & & \\
\hline & $1997-2000$ & 4 & & -8.1 & 12.8 & \\
\hline & $1997-1998$ & 2 & & & & \\
\hline & 1999-2000 & 2 & & & & \\
\hline \multirow{3}{*}{$\begin{array}{l}\text { Expansion: } \\
\text { below the trend } \\
\text { above the trend }\end{array}$} & 2001-2004 & 4 & \multirow{6}{*}{$\begin{array}{c}2001-2006 \\
6 \text { years }\end{array}$} & 6.9 & 15.0 & \multirow{6}{*}{1.2} \\
\hline & 2001 & 1 & & & & \\
\hline & 2002-2004 & 3 & & \multirow{4}{*}{-6.9} & \multirow{4}{*}{13.8} & \\
\hline \multirow{3}{*}{$\begin{array}{l}\text { Contraction: } \\
\text { above the trend } \\
\text { below the trend }\end{array}$} & 2005-2006 & 2 & & & & \\
\hline & 2005 & 1 & & & & \\
\hline & 2006 & 1 & & & & \\
\hline \multirow{3}{*}{$\begin{array}{l}\text { Expansion: } \\
\text { below the trend } \\
\text { above the trend }\end{array}$} & 2007-2009 & 3 & & \multirow[t]{3}{*}{5.9} & \multirow[t]{3}{*}{12.8} & \\
\hline & 2007 & 1 & & & & \\
\hline & 2008-2009 & 2 & 2007-2012 & & & 49 \\
\hline \multirow{3}{*}{$\begin{array}{l}\text { Contraction: } \\
\text { above the trend } \\
\text { below the trend }\end{array}$} & 2010-2012 & 3 & 6 years & \multirow[t]{3}{*}{-2.0} & \multirow[t]{3}{*}{7.9} & 4.9 \\
\hline & 2010 & 1 & & & & \\
\hline & 2011-2012 & 2 & & & & \\
\hline \multirow{3}{*}{$\begin{array}{l}\text { Expansion: } \\
\text { below the trend } \\
\text { above the trend }\end{array}$} & 2013 & 1 & \multirow{6}{*}{$\begin{array}{c}2013-2015 \\
3 \text { years }\end{array}$} & \multirow[t]{3}{*}{5.5} & \multirow[t]{3}{*}{7.5} & \multirow{6}{*}{-10.1} \\
\hline & - & - & & & & \\
\hline & 2013 & 1 & & & & \\
\hline Contraction: & 2014-2015 & 2 & & \multirow[t]{3}{*}{-12.1} & \multirow[t]{3}{*}{17.6} & \\
\hline above the trend & 2014 & 1 & & & & \\
\hline below the trend & 2015 & 1 & & & & \\
\hline
\end{tabular}

Source: the author's own calculations based on GUS (1993-2017a).

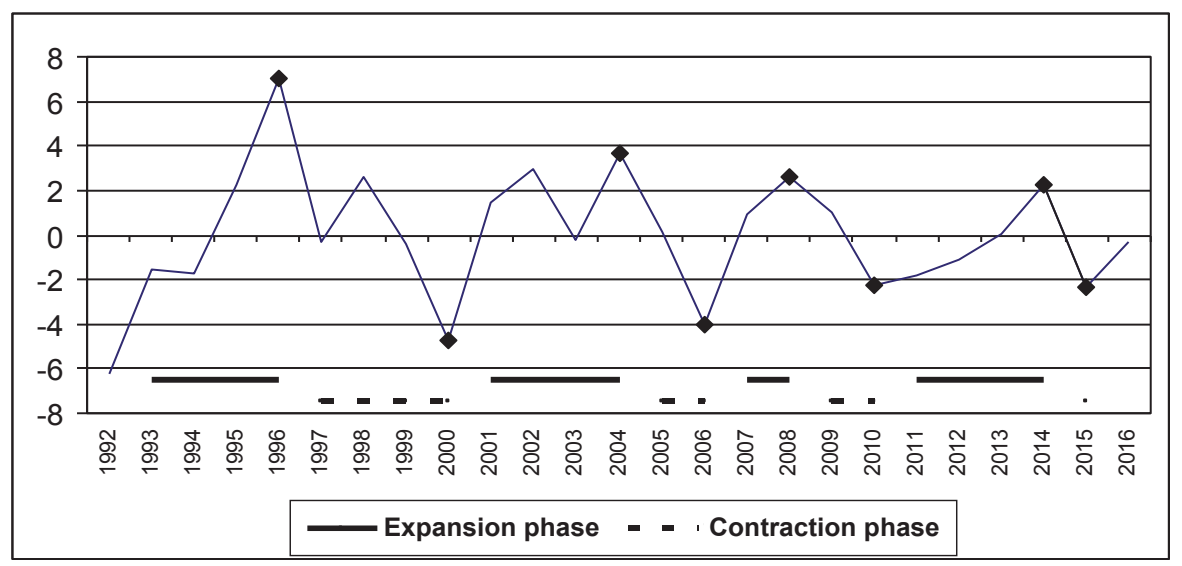

Fig. 5. Cyclical component of final agricultural output (\%).

Source: the author's study based on GUS (1993-2017a). 
Based on the cyclical component of final agricultural output in 1992-2016, three full business cycles in agriculture were identified. These cycles occurred in the following years: (1) 2001-2006; (2) 2007-2010; (3) 2011-2015 (Fig. 5). Just like in analysis of GDP changes, it may be risked to designate the fourth, almost full cycle, despite the fact that it was impossible to designate the trough prior to the expansion phase. This cycle lasted until mid-2000.

Table 4

Characteristics of the cyclical fluctuations in final agricultural output

\begin{tabular}{|c|c|c|c|c|c|c|}
\hline Cycle phase & $\begin{array}{l}\text { Period } \\
\text { of the cycle } \\
\text { phase }\end{array}$ & $\begin{array}{l}\text { Duration } \\
\text { of the phases } \\
\text { in years }\end{array}$ & $\begin{array}{c}\text { Period } \\
\text { and duration } \\
\text { of the cycle }\end{array}$ & $\begin{array}{l}\text { Peak/trough } \\
\text { deviation from } \\
\text { the trend (in pp) }\end{array}$ & $\begin{array}{l}\text { Amplitude } \\
\text { of the cycle } \\
\text { phases (pp) }\end{array}$ & $\begin{array}{l}\text { Amplitude } \\
\text { of the cycle } \\
\text { (pp) }\end{array}$ \\
\hline Expansion: & -1996 & - & \multirow{6}{*}{$\begin{array}{l}-2000 \\
8 \text { years }\end{array}$} & 7.1 & - & \multirow{6}{*}{ - } \\
\hline below the trend & 1993-1994 & - & & & & \\
\hline above the trend & 1995-1996 & 2 & & \multirow{4}{*}{-4.7} & \multirow{4}{*}{11.8} & \\
\hline Contraction: & $1997-2000$ & 4 & & & & \\
\hline above the trend & 1997-1998 & 2 & & & & \\
\hline below the trend & 1999-2000 & 2 & & & & \\
\hline Expansion: & 2001-2004 & 4 & \multirow{6}{*}{$\begin{array}{c}2001-2006 \\
6 \text { years }\end{array}$} & 3.7 & 8.4 & \multirow{6}{*}{0.7} \\
\hline below the trend & 2001 & 1 & & & & \\
\hline above the trend & $2002-2004$ & 3 & & \multirow{4}{*}{-4.0} & \multirow{4}{*}{7.7} & \\
\hline Contraction: & $2005-2006$ & 2 & & & & \\
\hline above the trend & 2005 & 1 & & & & \\
\hline below the trend & 2006 & 1 & & & & \\
\hline \multirow{3}{*}{$\begin{array}{l}\text { Expansion: } \\
\text { below the trend } \\
\text { above the trend }\end{array}$} & 2007-2008 & 2 & \multirow{6}{*}{200} & \multirow[t]{3}{*}{2.6} & \multirow[t]{3}{*}{6.6} & \\
\hline & - & - & & & & \\
\hline & 2007-2008 & 2 & & & & 18 \\
\hline \multirow{3}{*}{$\begin{array}{l}\text { Contraction: } \\
\text { above the trend } \\
\text { below the trend }\end{array}$} & 2009-2010 & 2 & & \multirow[t]{3}{*}{-2.2} & \multirow[t]{3}{*}{4.8} & \\
\hline & 2009 & 1 & & & & \\
\hline & 2010 & 1 & & & & \\
\hline \multirow{3}{*}{$\begin{array}{l}\text { Expansion: } \\
\text { below the trend } \\
\text { above the trend }\end{array}$} & 2011-2014 & 4 & \multirow{6}{*}{$\begin{array}{c}2011-2015 \\
5 \text { years }\end{array}$} & \multirow[t]{3}{*}{2.3} & \multirow[t]{3}{*}{4.5} & \multirow{6}{*}{-0.1} \\
\hline & 2011-2013 & 3 & & & & \\
\hline & 2014 & 1 & & & & \\
\hline Contraction: & 2015 & 1 & & \multirow[t]{3}{*}{-2.3} & \multirow[t]{3}{*}{4.6} & \\
\hline above the trend & - & - & & & & \\
\hline below & 2015 & 1 & & & & \\
\hline
\end{tabular}

Source: the author's own calculations based on GUS (1993-2017a).

The duration of the cycles in agriculture based on final output ranged from 4 to approx. 8 years. The longest fluctuations occurred before 2001. In one cycle, the duration of the expansion and contraction phases had the same lengths, while in the other two full cycles the expansion phases lasted much longer than the contraction ones (Table 4). The amplitude of two cycles was positive. In one cycle it was slightly negative (2011-2015). This means that the expansion phases in the cycles were usually more dynamic than the contraction ones. 
Two expansion phases lasted for four years. The phases starting in 1996 and in 2001-2004 coincided with periods of prosperity in aggregate economic activity. However, in 2011-2014, this coincidence was only partial. The contractions lasted from one to four years. The highest amplitude of the period of prosperity in agriculture occurred in 2001-2004, and the lowest one in 2011-2014. The most dynamic contraction phase occurred in 1997-2000 (11.8 pp), and the least dynamic one was recorded in 2015 (4.6 pp). The distribution of the expansion phases into the periods below and above the trend was always uneven. The opposite situation occurred in the contraction phases, in which a proportional distribution into periods above and below the trend was present almost always.

Table 5

Comparison of the cycle of gross value added and final output in agriculture

\begin{tabular}{ccccccc}
\hline \multirow{2}{*}{$\begin{array}{c}\text { Cycle } \\
\text { and phases }\end{array}$} & Period & $\begin{array}{c}\text { Amplitude } \\
\text { (pp) }\end{array}$ & $\begin{array}{c}\text { Peak/trough } \\
\text { trend (pp) }\end{array}$ & Period & $\begin{array}{c}\text { Amplitude } \\
(\mathrm{pp})\end{array}$ & $\begin{array}{c}\text { Peak/trough }- \\
\text { trend (pp) }\end{array}$ \\
\cline { 2 - 6 } Cycle & $1996-2000$ & -3.5 & - & -2000 & - & - \\
Expansion & 1996 & 9.3 & 4.7 & -1996 & - & 7.1 \\
Contraction & $1997-2000$ & 12.8 & -8.1 & $1997-2000$ & 11.8 & -4.7 \\
\hline Cycle & $2001-2006$ & 1.2 & - & $2001-2006$ & 0.7 & - \\
Expansion & $2001-2004$ & 15.0 & 6.9 & $2001-2004$ & 8.4 & 3.7 \\
Contraction & $2005-2006$ & 13.8 & -6.9 & $2005-2006$ & 7.7 & -4.0 \\
\hline Cycle & $2007-2012$ & 4.9 & - & $2007-2010$ & 1.8 & - \\
Expansion & $2007-2009$ & 12.8 & 5.9 & $2007-2008$ & 6.6 & 2.6 \\
Contraction & $2010-2012$ & 7.9 & -2.0 & $2009-2010$ & 4.8 & -2.2 \\
\hline Cycle & $2013-2015$ & -10.1 & - & $2011-2015$ & -0.1 & - \\
Expansion & 2013 & 7.5 & 5.5 & $2011-2014$ & 4.5 & 2.3 \\
Contraction & $2014-2015$ & 17.6 & -12.1 & 2015 & 4.6 & -2.3 \\
\hline
\end{tabular}

Source: the author's own calculations based on GUS (1993-2017a).

In the theoretical part of the study, it was pointed out that currently fluctuations in agricultural output depend on the economic situation in the national and global economies. In Poland, the accelerating GDP growth was recorded in 2002-2004, 2006-2007, 2010-2011 and 2014-2015. In the remaining years, the GDP growth rate was decreasing. These changes were mainly due to the monetary policy of the National Bank of Poland. Before each expansion, interest rates were lowered (Podstawowe..., 2018). This is in line with the business cycle theories developed by mainstream schools and the Austrian School. The determined periods of cycles and particular phases in agriculture usually coincide with the periods of changes in gross domestic product in the Polish economy. But sometimes there are time delays. Greater delays refer to the changes in the gross value added in agriculture than final output. Sectoral lags in relation to GDP are normal. They result from specific conditions prevailing in the sector at a given period. Besides changes in domestic output, agricultural output was also influenced by prices of agricultural products, influenced by world prices, as well as applied agricultural policy instruments. 
Without detailed analyses concerning the causes and interdependencies in the cyclical fluctuations in the Polish agriculture it is difficult to assess the usefulness of respective theories to explain the issue. In general, it may be assessed that the most promising direction of explaining the cyclicality in agriculture is the search for relations between changes in production and prices, including in the sector and the entire economy. Using the theory of production structure by the Austrian School of economy should explain higher growth rate in agriculture than in other sectors of the economy in respective phases of the business cycle.

The analysis of the findings presented in Table 5 allows for a comparison of the course of the business cycle in the Polish agriculture measured by gross value added and final output. The first observation concerns the number of identified cycles. Using GVA, four full cycles were identified, whereas the analysis of changes in final output enabled identifying one cycle less. There are similarities and differences in the duration of particular cyclical fluctuations. Since 2001, the duration of the cycles identified with the use of these categories has been in the range of 3-6 years. Fluctuations in 2001-2006 had the same duration, while the last two cycles had different lengths. The cycle which began in 2007 lasted for two years longer in the case of gross value added. The opposite situation occurred in the last cycle, which was much shorter in terms of GVA than in the case of final output. The year of cessation of these cyclical fluctuations was the same, as opposite to the time of their beginning. The differences in the duration of these cycles may be due to the different impact of production changes in aggregate economic activity on gross value added and final output in agriculture, as well as farm behaviours affecting these values differently due to the EU financial framework ending in 2013. Naturally, differences occurred also in the lengths of particular phases of these two cycles.

The identified cycles can be compared with the findings of other authors. In 2000-2016, economists of the Institute of Agricultural and Food Economics - National Research Institute identified, based on a synthetic business climate index, four full cycles in agriculture: (1) 2002-2005; (2) 2005-2008; (3) 2008-2012; (4) 2012-2015 (Seremak-Bulge, 2000-2016). Researchers from the Collegium of Economic Analysis of Warsaw School of Economics identified, based on the business climate index in agriculture, also four full cycles. However, their lengths were different: (1) 2000-2003; (2) 2003-2006; (3) 2006-2009; (4) 2009-2015 (Szajner and Walczyk, 2016-2018; Gorzelak and Zimny, 2010-2014). Using gross value added and final output in the period from 2000, one cycle fewer was identified. This follows from differences in the research method, construction of business cycle indicators and frequency of obtaining data.

Comparison of the dynamics of particular phases and the entire cycle in agriculture determined based on gross value added and final output allows for conclusion that cycles based on these categories differ significantly in this aspect (Table 5). First of all, the amplitude of each full cycle and each phase of the gross value added cycle is greater in absolute terms than the amplitudes relating to final output. Second of all, cycles based on final output are more likely to show significant symmetry in the dynamics between expansions and contractions. In the case of gross value 
added fluctuations, such symmetry occurred only once, in 2001-2006. In the other cycles there was significant asymmetry. The greatest asymmetry occurred in 2013-2015. Thirdly, the peak/trough distances from the trend of the gross value added dynamics were similar in only one cycle. In the case of the final output dynamics, these distances were similar in almost every cycle.

\section{Summary}

Cyclical fluctuations in agriculture are a relatively little examined issue compared to analyses of changes in aggregate economic activity, as well as the sectors of key importance to the production of domestic output. In Poland, the longest and the most systematic research into the economic situation in this sector is conducted at the Institute of Agricultural and Food Economics and the Collegium of Economic Analysis of Warsaw School of Economics. This research is based on changes in the price relations of goods sold and bought by farms, potential demand and farmer' opinions on the economic situation in agriculture.

In the study, the examination of the business cycle in agriculture was based on annual real changes in gross value added and final output in this sector. In the analysed 1991-2016 period, four full cycles were identified in Poland based on GVA: (1) 1996-2000; (2) 2001-2006; (3) 2007-2012; (4) 2013-2015. Using the GDP, it was stated that also in this case it is possible to designate the same number of cycles. (1) up to 2000; (2) 2001-2006; (3) 2007-2010; (4) 2011-2015. The beginning and end of the cycle in accordance with these categories coincide in only one case. Analysis of fluctuations showed - overlooking the first cycle lasting up to 2000 - that all cycles lasted from 3 to 6 years. Whereas phases most often lasted from 2 to 4 years. It was not found that the expansion phase lasted systematically longer than the contraction one. In two GVA cycles the time of better business cycles was shorter than the recession.

The most significant differences concerned the dynamics of the examined categories. The analysis of the original data showed that final agricultural output was more stable than gross value added. The same conclusion holds true for the cyclical component of these categories. The amplitude of the full GVA cycle, as well as its particular phases, was always higher in absolute terms than the amplitude of the cycle and phases of the GDP. Information contained in these categories is significantly different. The values of final output were more than twice greater than the value added. The obtained results are sensitive to assumptions and the used method.

The issue of cyclicality in agriculture requires research on a more extensive scale. This will allow for broader and more diversified view of the the phenomenon. What is important is assessment, basing on current data, links between the cycle in agriculture and in the entire economy. An interesting direction of research is the use of the theory of production structure of the Austrian School of economics to determine the relations between the production growth rate and the prices in agriculture and changes in these categories in the sector generating means of production and in the food industry. 


\section{References}

Barczyk, R. (2000-2001). Metodologiczne problemy diagnozowania współczesnych wahań koniunkturalnych. Polityka Gospodarcza, No. 5-6, pp. 43-58.

Barczyk, R., Kąsek, L., Lubiński, M., Marczewski, K. (2006). Nowe oblicza cyklu koniunkturalnego. Warszawa: PWE.

Barczyk, R., Lubiński, M., Małecki, W. (2014). Banki a cykl koniunkturalny. Warszawa: Oficyna Wydawnicza SGH.

Burns, A.F., Mitchell, W.C. (1946). Measuring Business Cycles. Studies in Business Cycles. New York: National Bureau of Economic Research.

Cameron, R., Neal, L. (2004). Historia gospodarcza świata. Warszawa: Książka i Wiedza.

Chavas, J.P. (1999). On the Economic Rationality of Market Participants: The Case of Expectations in the U.S. Pork Market. Journal of Agricultural and Resource Economics, No. 24, pp. 19-37.

Chavas, J.P., Holt, M. (1995). Nonlinear Dynamics and Economic Instability: The Optimal Management of a Biological Population. Journal of Agricultural and Resource Economics, No. 20(2), pp. 231-246.

Czyżewski, A., Kułyk, P. (2017). Wpływ zmian w otoczeniu makroekonomicznym na rozwój rolnictwa w krajach wysokorozwiniętych w długim okresie. Prace Naukowe Uniwersytetu Ekonomicznego we Wroclawiu, No. 491, pp. 86-96.

Drozdowicz-Bieć, M. (2012). Cykle i wskaźniki koniunktury. Warszawa: Poltext.

Dudek, A. (2014). Koniunktura w polskim rolnictwie na tle sytuacji ogólnogospodarczej w latach 1996-2012. Roczniki Naukowe Ekonomii Rolnictwa i Rozwoju Obszarów Wiejskich, No. 101(2), pp. 7-19.

Estey, J.A. (1959). Cykle koniunkturalne. Warszawa: PWG.

Ezekiel, M. (1938). The Cobweb Theorem. The Quarterly Journal of Economics, vol. 52, No. 2, pp. 255-280.

Friedman, M., Schwartz, A.J. (1963). Money and Business Cycles. Review of Economics and Statistics, vol. 45, No. 1, pp. 32-78.

Garrison, R.W. (2001). Time and Money. The Macroeconomics of Capital Structure. London-New York: Routledge.

Gorzelak, E., Zimny, Z. (2010-2014). Koniunktura w rolnictwie. Warszawa: Instytut Rozwoju Gospodarczego SGH.

Grzelak, A. (2013). Cykle koniunkturalne w rolnictwie na tle ogólnogospodarczych w Polsce podobieństwa i różnice. Roczniki Naukowe SERiA, vol. XV, issue 2, pp. 86-91.

Grzelak, A. (2014). Koniunktura w rolnictwie w Polsce w świetle wybranych metod. Roczniki Naukowe SERiA, t. XVI, z. 2, pp. 68-72.

Grzelak, A., Seremak-Bulge, J. (2014). Porównanie wybranych metod badania koniunktury w rolnictwie w Polsce. Zagadnienia Ekonomiki Rolnej, No. 4(341), pp. 117-130.

GUS (2012-2018). Koniunktura w gospodarstwach rolnych. Warszawa: GUS.

GUS (1993-2017a). Rocznik Statystyczny Rolnictwa. Warszawa: GUS.

GUS (1997-2017b). Rocznik Statystyczny RP. Warszawa: GUS.

Hamulczuk, M. (2006). Cykliczne zmiany na rynku trzody chlewnej w Polsce. Roczniki Nauk Rolniczych. Seria G, vol. 92, issue. 2, pp. 42-51.

Hansen, A.H. (1932). The business cycle and its relation to agriculture. Journal of Farm Economics, vol. 14, No. 1, pp. 59-60. 
Huerta de Soto, J. (2010). Socialism, economic calculation and entrepreneurship. Edward Elgar: Cheltenham.

Jevons, W.S. (1978). Commercial crises and sunspots. Nature, No. 19, pp. 33-37.

Jędruchniewicz, A. (2012). Inwestycje w rolnictwie a cykl koniunkturalny. Roczniki Naukowe SERiA, vol. 14, issue 1, pp. 213-216.

Kaletsky, A. (2010). Capitalism 4.0. The Birth of a New Economy. London: Bloomsbury.

Kowalczyk, B. (2011). Zastosowanie metody poststratyfikacji w badaniach koniunktury. Metody ilościowe w badaniach ekonomicznych, vol. XII/2, pp. 210-221.

Kwaśnicki, W. (2014). Panika roku 1907 - kryzys finansowy 2008. Sto lat budowania kreatywnego kapitalizmu. Ekonomia XXI Wieku, No. 2, pp. 9-33.

Lucas, R.E. (1987). Models of Business Cycles. Oxford: Basil Blackwell.

Lubiński, M. (2004). Analiza koniunktury i badanie rynków. Warszawa: Dom Wydawniczy Elipsa.

Mankiw, N.G., Romer, D. (1991). New Keynesian Economics. Cambridge: MIT Press.

Maśniak, J. (2015). Cykl koniunkturalny w rolnictwie z perspektywy austriackiej szkoły ekonomii. Zeszyty Naukowe SGGW, Ekonomika i Organizacja Gospodarki Żywnościowej, No. 111, pp. 111-121.

Matkowski, Z. (ed.) (2004). Composite indicators of business activity for macroeconomic analysis. Prace i Materiały IRG. Warszawa: SGH.

Mayer, T. (1996). Prawda kontra precyzja w ekonomii. Warszawa: Wydawnictwo Naukowe PWN.

Mintz, I. (1972). Dating American Growth Cycles. In: V. Zarnowitz (ed.), The Business Cycle Today. New York: National Bureau of Economic Research.

Morgan, M.S. (1990). The History of Econometric Ideas (Historical perspectives on modern economics). New York: Cambrigde University Press.

Mrówczyńska-Kamińska, A. (2008). Znaczenie rolnictwa w gospodarce narodowej w Polsce - analiza makroekonomiczna i regionalna. Zeszyty Naukowe SGGW, Problemy Rolnictwa Światowego, No. 5(XX), pp. 96-108.

O’Driscoll, G.P., Rizzo, M.J. (1996). The Economics of Time and Ignorance. London-New York: Routledge.

Plosser C.I. (1989), Understanding Real Business Cycle. Journal of Economic Perspectives, No. 3, pp. 53.

Podstawowe stopy procentowe NBP w latach 1998-2015. Retrieved from:www.nbp.pl, access date: 25.06.2018.

Romer, D. (2000). Makroekonomia dla zaawansowanych. Warszawa: PWN.

Rothbard, M.N. (2008). Ekonomia wolnego rynku. Vol. 3. Warszawa: Fijorr Publishing.

Roubini, N., Mim, S. (2011). Ekonomia kryzysu. Warszawa: Wydawnictwo Wolters Kluwer.

Róg, A., Strzała, K. (2011). Przydatność prognostyczna wskaźników testu koniunktury - przegląd metod ewaluacji. Prace i Materiały Wydziału Zarzadzania Uniwersytetu Gdańskiego, No. 4/8, pp. 513-522.

Ruth, F., Schouten, B., Wekker, R. (2006). The Statistics Netherlands Business Cycle TracerMethodological Aspects, Concept, Cycle Computation and Indicator Selection. Discussion Paper, Voorburg/Heerlen: Statistics Netherlands.

Schiff, P.D. (2015). Wielka depresja 2.0. Warszawa: Fijorr Publishing.

Seremak-Bulge, J. (2000-2016). Koniunktura w rolnictwie. In: J. Seremak-Bulge (ed.), Rynek rolny. Warszawa: IERiGŻ (as of 2005 IERiGŻ-PIB). 
Skousen, M. (2007). The Structure of Production. New York: NY University Press.

Sławiński, A. (2009). Przyczyny globalnego kryzysu bankowego. In: J. Osiński, S. Sztaba (ed.), Nauki społeczne wobec kryzysu na rynkach finansowych. Warszawa: SGH.

Snowdon, B., Vane, H. (2005). Modern macroeconomics: Its Origins, Development and Current State. London-New York: Routledge.

Stanley, J.W. (1878). Commercial crises and sun-spots. Nature, vol. XIX, pp. 33-37.

Stańko, S. (2012). Tendencje w produkcji i handlu zagranicznym wieprzowiną w Polsce w latach 1990-2011. Zeszyty Naukowe SGGW, Problemy Rolnictwa Światowego, No. 12(2), pp. 77-85.

Stępień, S. (2011). Związki wahań cyklicznych w rolnictwie z koniunkturą gospodarczą. Roczniki Nauk Rolniczych, Seria G, vol. 98, issue 3, pp. 32-41.

Stępień, S. (2015). Cykl świński w świetle zmian na globalnym rynku żywca wieprzowego. Poznań: Uniwersytet Ekonomiczny.

Stilman, R.P. (1984). Hog operations becoming fewer, larger and more efficient livestock and poultry. Livestock and Poultry Outlook and Situation Report. Washington: USDA.

Szajner, P., Walczyk, K. (2016-2018). Koniunktura $w$ rolnictwie. Warszawa: Instytut Rozwoju Gospodarczego SGH.

Szymańska, E. (2012). Zmienność koniunktury na rynku trzody chlewnej w Polsce. Roczniki Naukowe SERiA, vol. XIV, issue 1, pp. 524-528.

Tomek, W.G., Robinson, K.L. (2003). Agricultural Product Prices. Ithaca: Cornell University.

White, L.H. (1984). The Methodology of the Austrian School Economists. Auburn: The Ludwig von Mises Institute.

Wojtyna, A. (2000). Ewolucja keynesizmu a główny nurt ekonomii. Warszawa: PWN.

Wojtyna, A. (ed.) (2011). Kryzys finansowy i jego skutki dla krajów na średnim poziomie rozwoju. Warszawa: PWE.

Wojtyna, A. (2013). Kontrowersje wokół charakteru ożywienia po kryzysie finansowym i recesji. Gospodarka Narodowa, No. 11-12, pp. 5-21.

Woś, A. (1998). Koniunktura rolnicza In: Encyklopedia agrobiznesu. Warszawa: Fundacja Innowacja.

Zawadzka, D. (2006). Historia badań „cyklu świńskiego”. Zagadnienia Ekonomiki Rolnej, No. 4(309), pp. 48-58. 


\title{
CYKLICZNE WAHANIA PRODUKCJI POLSKIEGO ROLNICTWA
}

\begin{abstract}
Abstrakt
Głównym celem opracowania jest ilościowa charakterystyka cyklu koniunkturalnego $w$ rolnictwie w Polsce w latach 1991-2016. Pierwsza część artykułu poświęcona jest teorii wahań cyklicznych w rolnictwie. W części drugiej zostata przeprowadzona analiza empiryczna. Badanie cyklu koniunkturalnego $w$ rolnictwie oparte jest na rocznej dynamice wartości dodanej brutto oraz produkcji końcowej. Na podstawie wartości dodanej możliwe było określenie czterech pełnych cykli: 1) 1996-2000, 2) 2001-2006, 3) 2007-2012, 4) 2013-2015. Wykorzystujac produkcję końcowa, uznano, że także w tym przypadku, można wyznaczyć taka sama liczbe cykli: 1) do 2000, 2) 2001-2006, 3) 2007-2010, 4) 2011-2015. Cykle najczesściej miały długość od 3 do 6 lat. Natomiast fazy najcześsciej trwały od 2 do 4 lat. Na podstawie analizy wyciagnięto też wniosek, że amplituda całego cyklu wartości dodanej brutto, jak i jego poszczególnych faz, była zawsze, w ujęciu bezwzględnym, wyższa od amplitudy cyklu i faz produkcji końcowej. Największa amplituda, w ujęciu bezwzględnym, dotyczyła cyklu wartości dodanej brutto z lat 2013-2015.
\end{abstract}

Słowa kluczowe: cykl koniunkturalny, rolnictwo, wartość dodana brutto, produkcja końcowa rolnictwa.

Accepted for print: 18.12.2018.

Unless stated otherwise all the materials on the website are available under 